\title{
Investigation of the effects of current velocity on mussel feeding and mussel bed stability using an annular flume
}

Received: 12 December 2000 / Revised: 3 April 2001 / Accepted: 10 December 2001 / Published online: 9 February 2002

(C) Springer-Verlag and AWI 2002

\begin{abstract}
An annular flume was used to measure the effect of increasing current velocity on mussel (Mytilus edulis) feeding rate and the stability of mussel beds sampled from the mouth of the Exe estuary (SW England). It was found that, in contrast to earlier flume studies, the feeding rates of mussels from open coast sites were unaffected by current velocities up to $0.8 \mathrm{~m} \mathrm{~s}^{-1}$. Algal cell depletion in the water column above mussels was a function of current velocity, increasing with declining currents below $0.05 \mathrm{~m} \mathrm{~s}^{-1}$. The erodability/stability of the mussel bed, measured in terms of critical erosion velocity, sediment mass eroded and mean erosion rate, was found to be a function of the nature of the substrate and the density of the mussels. Erosion of mussel beds on sandy substrate showed a non-linear relationship with mussel bed density. In comparison with the sand $(0 \%$ mussel cover), sediment resuspension was about five and four times higher for $25 \%$ and $50 \%$ cover, respectively. This was due to the increased turbulence and scouring around the clumps of mussels in low-density parts of the bed, and this resulted in some mussels detaching from the bed. At $\sim 100 \%$ mussel cover, the sandy bed was more protected by the dense surface layer of mussels, and none became detached during erosion due to the high number of byssal attachments between individuals. The sediment resuspension from the $100 \%$ mussel cover was about three times lower than the $0 \%$ cover. Erosion of the bed with $50 \%$ cover resulted in burial of a large proportion of the mussels, with a $6 \mathrm{~cm}$ increase in sediment level. However, the mussels returned to the surface and recovered in 1-2 days, due to a combination of mi-
\end{abstract}

Communicated by H. Asmus and R. Asmus

J. Widdows $(\varangle) \cdot$ M.D. Brinsley $\cdot$ P.N. Salkeld · F.J. Staff Plymouth Marine Laboratory, Prospect Place, The Hoe, Plymouth PL1 3DH, UK e-mail: jwiddows@pml.ac.uk

Tel.: +44 1752633 100, Fax: +44 1752633101

J.S. Lucas

School of Marine Biology and Aquaculture,

James Cook University, Queensland 4811, Australia gration upwards and substrate settlement. Channels on the edge of the main Exmouth mussel bed were characterised by a more stable substrate comprising pebbles and sand with varying mussel densities. At these sites, where mussels experience high current velocities on spring tides (up to $0.9 \mathrm{~m} \mathrm{~s}^{-1}$ ), there was no difference between the erodability of pebble/sand substrate with $0 \%$ and $100 \%$ mussel cover. The sediment erosion was also lower than the $100 \%$ mussel cover on the sandy substrate, particularly at currents $>0.4 \mathrm{~m} \mathrm{~s}^{-1}$. Sampling of different parts of the mussel bed at Exmouth showed mussels at low densities were made up of smaller clumps with a lower mass ratio of mussels to attached substrate (pebbles/sand), thus providing a greater degree of anchorage.

Keywords Mussel beds - Mytilus edulis . Current velocity $\cdot$ Feeding rate $\cdot$ Annular flume

\section{Introduction}

Mussels (Myilus edulis) are sessile suspension-feeding bivalves that live in estuarine and coastal environments characterised by periods of strong tidal and waveinduced currents. While increasing water flow is beneficial to sustaining a plentiful supply of suspended food particles and oxygen, particularly in areas densely populated by mussels, there will inevitably be upper and lower limits of tolerance to current velocities. At high flows this may be the result of a direct physical impact on mussel performance, or the erosion/disturbance of the underlying sediment; while at reduced flows the mussels can influence their surrounding environment by depleting food downstream (Fréchette and Bourget 1985; Fréchette et al. 1993). At present, however, the impact of current velocity on the functioning of individual mussels and mussel beds is poorly quantified.

To date, various experimental studies have measured benthic-pelagic fluxes (i.e. feeding rate, sediment resuspension, nutrient exchange) associated with mussel beds 
under changing flow conditions. These have involved different types of flumes and benthic ecosystem tunnels, both in the laboratory (Wildish and Miyares 1990; Widdows et al. 1998a; Newell 1999) and in the field (Asmus et al. 1992; Asmus and Asmus 1993; Dame 1993; Prins et al. 1996). In situ flume and tunnel studies have relied upon the prevailing tidal currents and therefore no relationships between feeding rate or resuspension and current velocity have been established. Preliminary laboratory flume studies (Wildish and Miyares 1990; Newell 1999), however, have reported a reduction in feeding rate of M. edulis with increasing current velocity between 0.05 and $0.30 \mathrm{~m} \mathrm{~s}^{-1}$. In earlier annular flume studies (Widdows et al. 1998a), the influence of mussel bed density and current velocity on the sediment erodability (cohesive mud sediments) was quantified. The erosion of cohesive muds showed a linear relationship with current velocity and mussel bed density.

The main objectives of this study were to determine the effect of current velocity on the clearance rate of mussels (M. edulis) and to quantify sediment erodability in relation to current velocity, mussel bed density and the nature of the sediment/substrate.

\section{Materials and methods}

\section{Study site}

Mussels (M. edulis) were collected from extensive beds on Great Bull Hill (Grid reference SX 988811) at the mouth of the River Exe, SW England (see McGrorty et al. 1990 for site description). At this site the mussel beds are 1-2 $\mathrm{m}$ in height and the underlying substrate ranges from sand $(125-250 \mu \mathrm{m})$ to a mixture of sand and pebble stones $(0.5-3 \mathrm{~cm})$. Here the established mussel beds are exposed to strong tidal currents through the narrow mouth of the estuary, and at times of high fluvial flow during the winter there is evidence of deep erosion channels through the mussel beds.

Current velocities and suspended particulate matter (SPM) concentrations over the Exmouth mussel bed were recorded over two tidal cycles during a spring tide using a mini-rig. The rig consisted of an $x-y$ electromagnetic current meter (Valeport 800 with a $5.5 \mathrm{~cm}$ spherical head), an optical back-scatter sensor (OBS-1; D \& A Instruments) both at a height of $10 \mathrm{~cm}$ above the bed, and a depth pressure sensor (Druck PDCR 940, 0-7 Bar absolute) on the sediment surface. Outputs from the instruments were logged every $0.5 \mathrm{~s}$ for a period of 3 min every $12 \mathrm{~min}$ throughout a tidal cycle.

\section{Effect of current velocity on suspension feeding}

All experiments were carried out at the Plymouth Marine Laboratory using recirculating, high quality offshore seawater maintained at $15^{\circ} \mathrm{C}$ and 33 psu and mussels were fed with an algal diet of Isochrysis galbana. The suspension-feeding rates of mussels in relation to current velocity were determined in an annular flume. Details of the flume and the operating procedures are described by Widdows et al. (1998b). In summary, the flume represents a smaller, modified version of the design described by Fukada and Lick (1980). The annular flume is constructed of acrylic material with a $64 \mathrm{~cm}$ (outer) and $44 \mathrm{~cm}$ (inner) diameter, resulting in a $10 \mathrm{~cm}$ channel width with a total bed area of $0.17 \mathrm{~m}^{2}$, a maximum water depth of $38 \mathrm{~cm}$, and a maximum volume of $60 \mathrm{l}$. In this study, six small acrylic blocks or shallow paddles were attached to the smooth drive plate to increase the water current velocity generated at a given number of revolutions per minute. Current velocities ranged from 0.004 to $1.2 \mathrm{~m} \mathrm{~s}^{-1}$, the maximum depending on the bed roughness and friction exerted by the bed. The drive plate speed was monitored using an infrared photo switch and recorded every 15 s by a data-logger.

An electromagnetic (EM) current flow meter with a small discus sensor (Valeport Model 800-175) was used to measure the vertical profiles in current velocities in relation to the rotation speed of the drive plate. The presence of two orthogonal pairs of electrodes enabled measurement of flow velocities in two axes, the primary tangential flow and the secondary radial flow. The use of a $10 \mathrm{~cm}$ channel width in the present flume minimized the problem of secondary flows usually associated with wider annular flumes (see Fukada and Lick 1980). The EM current flow meter confirmed that there was no significant/detectable radial flow below free-stream current velocities of $\sim 0.8 \mathrm{~m} \mathrm{~s}^{-1}$, and above this the radial flow was approximately $2-5 \%$ of the main tangential flow.

Sea water can flow in and out of the flume (open system) via side-ports (10 $\mathrm{mm}$ bore) which are fitted tangentially to the outer wall of the flume. When the inflow is stopped the flume operates as a closed system. Water can be sampled from seven different heights $(3,6,10,15,20,25$ and $30 \mathrm{~cm}$ above the bed), via syringes connected to $2 \mathrm{~mm}$ bore tubes in the outer wall of the flume, to determine the temporal and vertical profile of algal cell concentration. Cell concentrations were determined by means of an electronic particle counter (Coulter Counter Multisizer), using a $100 \mu \mathrm{m}$ orifice tube. Preliminary flume experiments without mussels established that there was sufficient vertical mixing to produce a homogeneous algal cell concentration throughout the flume within 5 min of their addition to the flume, whilst running at low current velocities (i.e. $0.004-0.06 \mathrm{~m} \mathrm{~s}^{-1}$ ).

A group of 20 mussels ( $4.5 \mathrm{~cm}$ shell length) was placed in the first quadrant (i.e. $0-90^{\circ}$ sector) and left overnight to attach to the flume base by byssal threads. Between experiments at different current velocities, mussels were maintained in the flume with flowing sea water (open flow) and were fed continuously with algal cells to give a cell concentration of 6,000 cells ml- $^{-1}$. Before each feeding rate/current velocity experiment the flow was stopped and the faeces siphoned from the flume to avoid their resuspension. The flume water was replenished and switched to a 'closed system'. Mussels were then acclimatised to a given current speed for $15 \mathrm{~min}$, prior to the addition of algal cells to the flume to give an initial concentration of 12,000 cells $\mathrm{ml}^{-1}$. Water samples were then taken after 5 min mixing time and thereafter at 20-min intervals over the time course of $1 \mathrm{~h}$.

Suspension feeding, measured in terms of clearance rate (i.e. the volume of water cleared of algal cells per hour), was calculated from the exponential decline in cell concentration using the following equation:

$C R\left(l h^{-1}\right)=V *\left(\log _{e} C_{1}-\log _{e} C_{2}\right) / t$

where $V$ is the volume of water in the flume (litres), $t$ is the time interval in hours, and $C_{1}$ and $C_{2}$ are the algal cell concentrations at the beginning and end of each time increment (20 min intervals).

Algal cell depletion in relation to current velocity was examined by sampling, via syringe, from different heights in the water column immediately downstream of the group of mussels within the flume (i.e. at $90^{\circ}$ ). Algal cell concentration was determined by electronic Coulter Counter and expressed relative to the cell concentration in the upper water column $(30 \mathrm{~cm}$ height $)$.

\section{Sediment erodability in relation to mussel bed density}

The mussel bed, with different densities or percentage cover, together with the underlying sediment at Exmouth, was cored with minimal disturbance following the method used by Widdows et al. (2000). Cores were taken to a depth of $\sim 10 \mathrm{~cm}$ by means of stainless steel quadrant box cores (four cores forming an annulus of $64 \mathrm{~cm}$ outer and $44 \mathrm{~cm}$ inner diameter) designed to fit precisely into the flume. The stainless steel quadrant cores were first pushed into the sediment and then dug out, allowing base plates to be inserted at the bottom of the cores. This enabled the cores to be lift- 
ed, and bands to be placed around them to retain the base and sediment during transportation to the flume. The quadrant box cores were carefully inserted into the annular flume and the stainless steel boxes were then removed, leaving the mussels, sediment and base plates in the flume to create a continuous substrate. The bed was then allowed to settle for several days in flowing sea water before the erosion experiment was initiated. Different parts of the Exmouth mussel bed were selected to give a range of mussel densities and substrates for different experiments. Sandy substrates were more representative of the centre of the Exmouth mussel bed and pebble/sandy substrates were from channels towards the eastern edge of the bed.

Mussel bed erosion experiments consisted of quantifying the suspended particulate matter (SPM) concentrations $\left(\mathrm{mg} \mathrm{l}^{-1}\right)$, mass of sediment eroded $\left(\mathrm{g} \mathrm{m}^{-2}\right)$ and the sediment erosion rate $\left(\mathrm{g} \mathrm{m}^{-2} \mathrm{~s}^{-1}\right)$ in response to a stepwise increase in current velocity from 0.1 to $>0.7 \mathrm{~m} \mathrm{~s}^{-1}$, each with a duration of $15 \mathrm{~min}$. Erosion, or the suspension of sediment, was determined by frequent monitoring (i.e. $15 \mathrm{~s}$ intervals) by an optical backscatter sensor (OBS-3; D \& A Instruments) and the output was recorded on a data-logger. The OBS sensor was calibrated against water samples taken for gravimetric analysis and calibration curves were produced for each experiment/sediment type. Mean erosion rate $\left(E_{\text {mean }}\right)$ was calculated over the first $10 \mathrm{~min}$ at each current velocity. Measurements were also supplemented by video recording (SONY Hi-8) of observed phenomena and processes within the flume.

Mussel and sediment heights were determined at $10^{\circ}$ intervals around the flume at the beginning (at minimum velocities) and end (at maximum velocities) of each experimental run. The sizefrequency distribution of attached and any detached mussels were measured at the end of the experiments. Exmouth mussel bed density and size-frequency distribution was estimated from four $0.05 \mathrm{~m}^{2}$ quadrats. In addition, the relationship between degree of mussel anchorage to sediment/stones and mussel bed density was measured in a field survey. Mussels of different clump size were collected from the Exmouth mussel bed and analysed in terms of total weight of mussels and the total mass of pebbles/sediment attached.

The vertical profile in current velocity above the mussel bed was measured using the EM current meter. In this study, the results are related to current velocities in preference to bed shear stress, as the former parameter can be quantified directly and with a greater degree of accuracy, both in the flume and in the field (at $z=10 \mathrm{~cm}$ above the bed). In contrast, shear stress is estimated indirectly assuming a log velocity profile, but such profiles are rarely recorded in the field due to shallow water depth and the presence of accelerating or decelerating tidal currents (Collins et al. 1981; J. Widdows and P.N. Salkeld, unpublished data).

Statistical analysis of the data was performed using ANOVA and ANCOVA (Systat v7 for Windows).

\section{Results}

\section{Feeding rate}

The effect of free-stream current velocity on clearance rate of mussels $\left(\mathrm{h} \mathrm{h}^{-1}\right.$ individual $\left.^{-1}\right)$ is illustrated in Fig. 1. Clearance rate was maintained independent of current velocities up to $0.8 \mathrm{~m} \mathrm{~s}^{-1}$, with mussels extending their mantle edges fully into the currents (i.e. there was no adverse behavioural response). Above $0.8 \mathrm{~m} \mathrm{~s}^{-1}$ the clearance rates declined from 3.3 to $1.8 \mathrm{l} \mathrm{h}^{-1}$ individual $^{-1}$, but this was largely associated with the detachment of mussels. However, they were still open and filtering whilst moving around the flume. Clearly, a longer period of time is required for byssal attachment before it is possible to measure feeding rates at the higher current velocities. There was also a slight but not statistically significant decline in feeding rate at the current velocities below $0.05 \mathrm{~m} \mathrm{~s}^{-1}$. This was probably due to algal cell depletion and greater recirculation of near bed water by the group of mussels (see below).

At current velocities $>0.06 \mathrm{~m} \mathrm{~s}^{-1}$ there was sufficient vertical mixing and a relatively constant algal cell concentration down the water column (Fig. 2). At lower currents there was increasing cell depletion around the mussels with declining current velocity. The degree and height of the significantly algal depleted water extended to $5 \mathrm{~cm}$ at $0.02 \mathrm{~m} \mathrm{~s}^{-1}, 10 \mathrm{~cm}$ at $0.008 \mathrm{~m} \mathrm{~s}^{-1}$ and $15 \mathrm{~cm}$ at $0.004 \mathrm{~m} \mathrm{~s}^{-1}$.

\section{Impact of the bed on current velocities}

Mussel beds interact strongly with the flow, extracting momentum from the fluid via hydrodynamic drag and generating turbulence via disruption. The increase in bed friction due to the changes in bed roughness length (no sediment, sandy substrate and mussels overlying sand) is reflected in the relationship between the speed (rpm) of the flume drive plate and the free-stream current velocity (Table 1). With increasing bed roughness length there is
Fig. 1 Effect of free-stream current velocity on the clearance rate of mussels (Mytilus edulis). Mean $\pm 95 \%$ CI based on five replicate experiments

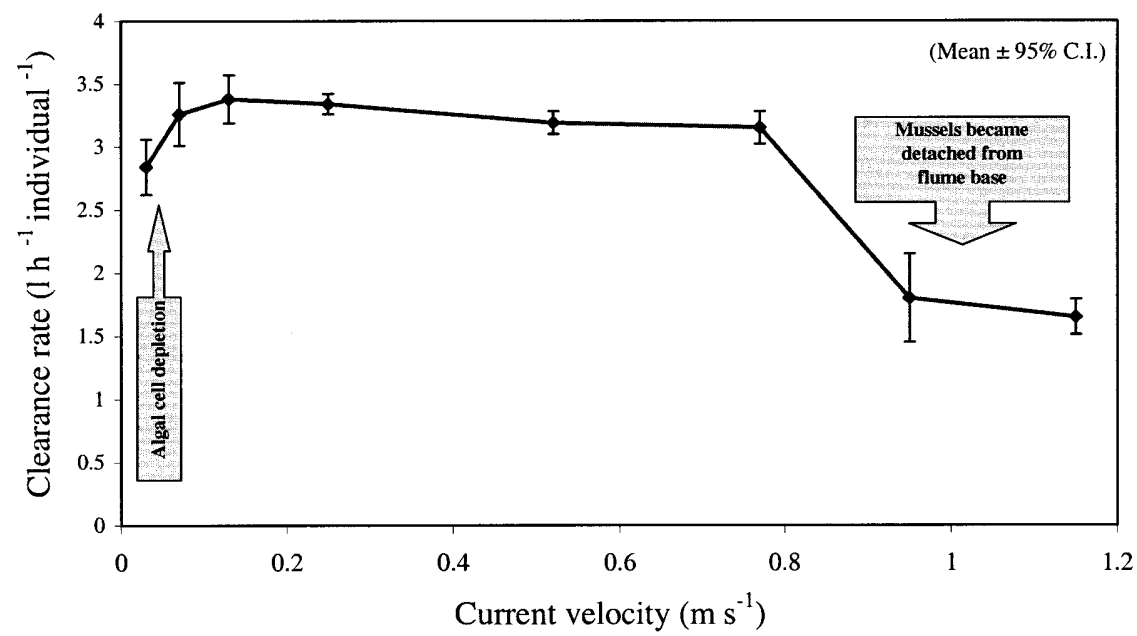


Fig. 2 Vertical profile of algal cell concentration as a function of current velocity showing algal cell depletion immediately above mussels at low current velocities $\left(<0.06 \mathrm{~m} \mathrm{~s}^{-1}\right)$. Algal cell concentration is expressed relative to concentration at $30 \mathrm{~cm}$ height $(\%)$
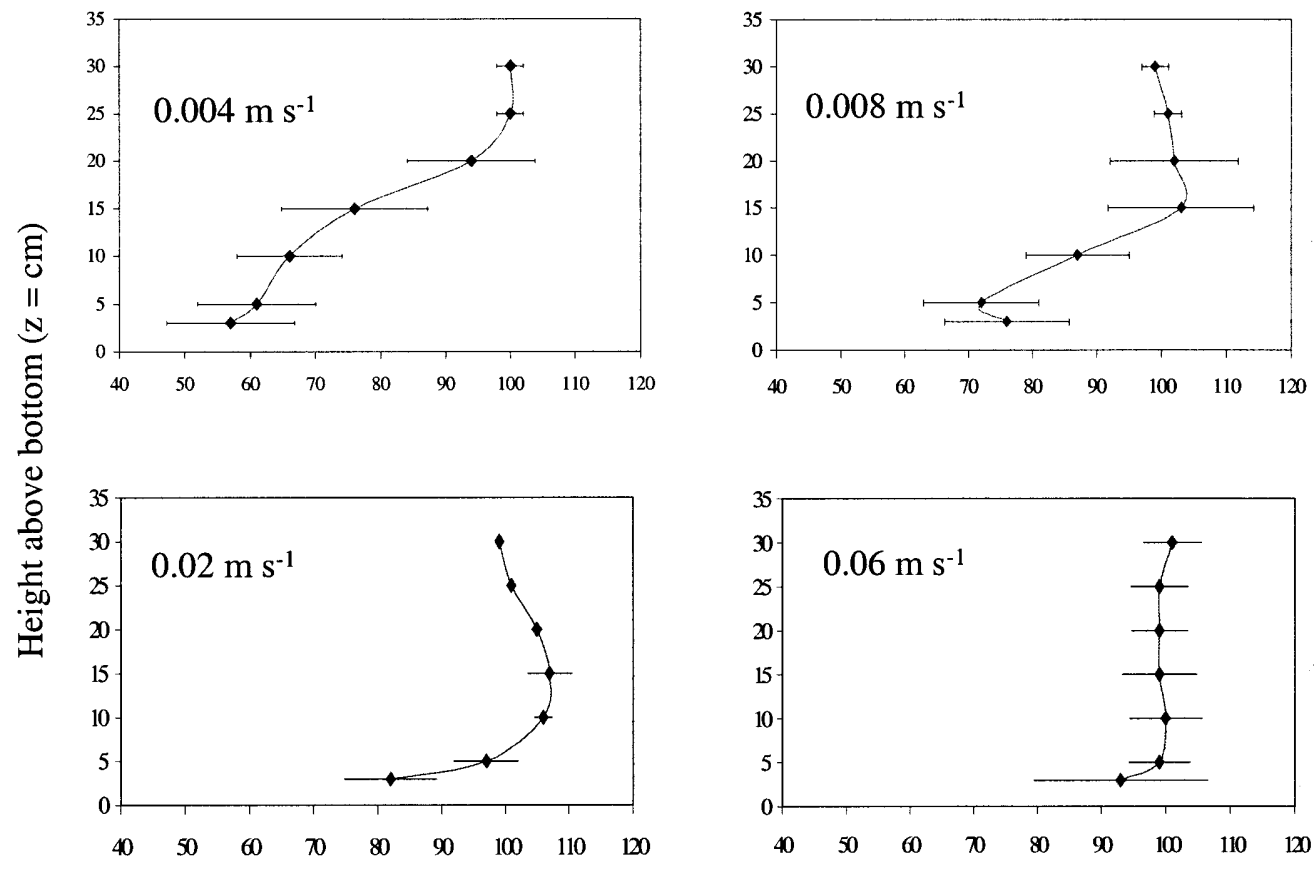

Algal cell concentration relative to $30 \mathrm{~cm}$ height (\%)

Fig. 3 Time course of sediment erosion (mass eroded and mean erosion rate) in response to a step-wise increase in freestream current velocity (Experiment: sandy substrate with $100 \%$ mussels cover)

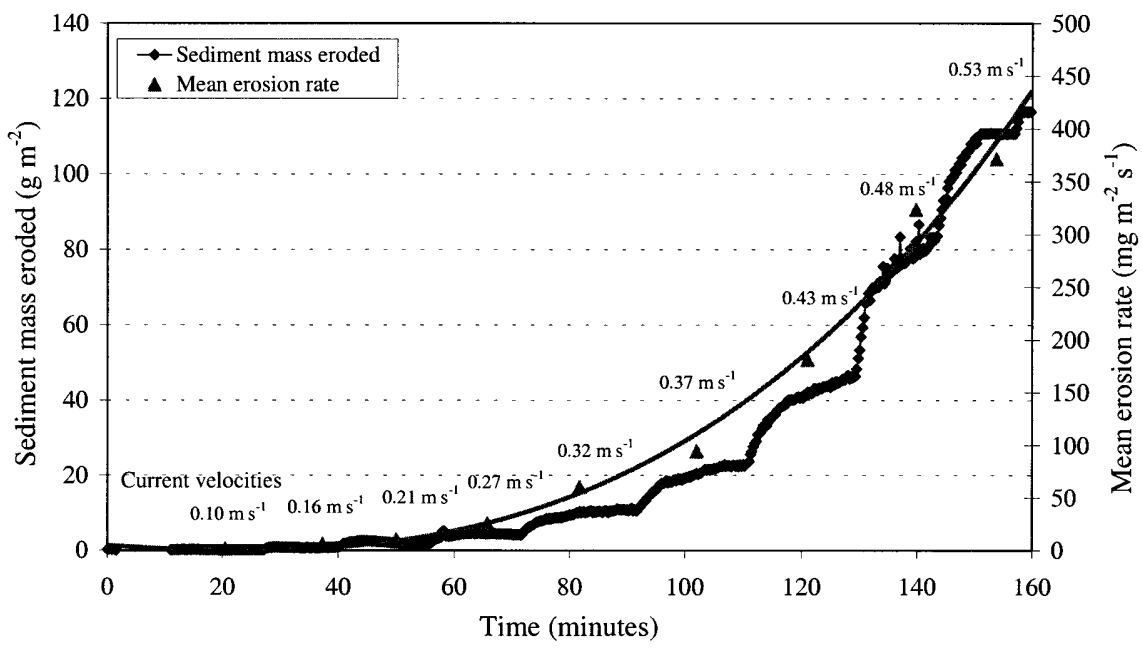

Table 1 Equations describing the relationship between speed (rpm) of annular flume drive plate ( $x$; revolutions per minute) and measured free-stream current velocity $\left(y ; \mathrm{m} \mathrm{s}^{-1}\right)$ above different substrates. All are significantly different from one another at $P<0.001$ (ANCOVA). Mussel bed density at $100 \%$ coverage was 3,540 individuals $\mathrm{m}^{-2}$, their sizes ranged from 10 to $65 \mathrm{~mm}$ and the population had a bimodal distribution (20 and $45 \mathrm{~mm})$

\begin{tabular}{ll}
\hline Substrate & Equation \\
\hline No substrate (flume base) & $y=0.0202 x, r^{2}=0.997$ \\
Sandy substrate & $y=0.0138 x, r^{2}=0.978$ \\
Mussel bed (100\% cover) & $y=0.0105 x, r^{2}=0.995$ \\
\hline
\end{tabular}

a significant reduction in the current velocity generated by a given drive plate speed (ANCOVA, $P<0.001$ ). The vertical profiles in current velocities immediately above a mussel bed $\left(100 \%\right.$ cover or 3,540 mussels $\mathrm{m}^{-2}$;
Table 1) are complex in nature due to turbulence created by the mussels. Many natural environments, particularly shallow water estuarine systems, have complex flow regimes with non-logarithmic velocity profiles in the boundary layer (Paterson and Black 1999) and this prevents an accurate estimate of the bed shear stress. Consequently, the results of this study are expressed in relation to free-stream velocity $(6-10 \mathrm{~cm}$ above the mussels).

Sediment erodability in relation to mussel bed density and the nature of the substrate

Figure 3 illustrates the time-course of erosion in response to a step-wise increase in free-stream current velocity (sandy substrate with $100 \%$ mussel cover). Sediment resuspension is continuously monitored by the 
Fig. 4 Effect of current velocity on sediment mass eroded from sandy substrate with different mussel bed densities (\% cover). Open and closed circles represent replicate flume experiments at $100 \%$ mussel density
Fig. 5 Regression lines describing sediment mass eroded (log transformed) from sandy substrate in relation to increasand different mussel bed densities (\% cover). Open and closed circles represent replicate flume experiments at $100 \%$ mussel density. Horizontal broken line represents the threshold for defining critical erosion velocity $\left(U_{\text {crit }}\right)$. Vertical arrows indicate $\mathrm{U}_{\text {crit }}$ for the four mussel densities ing free-stream current velocity
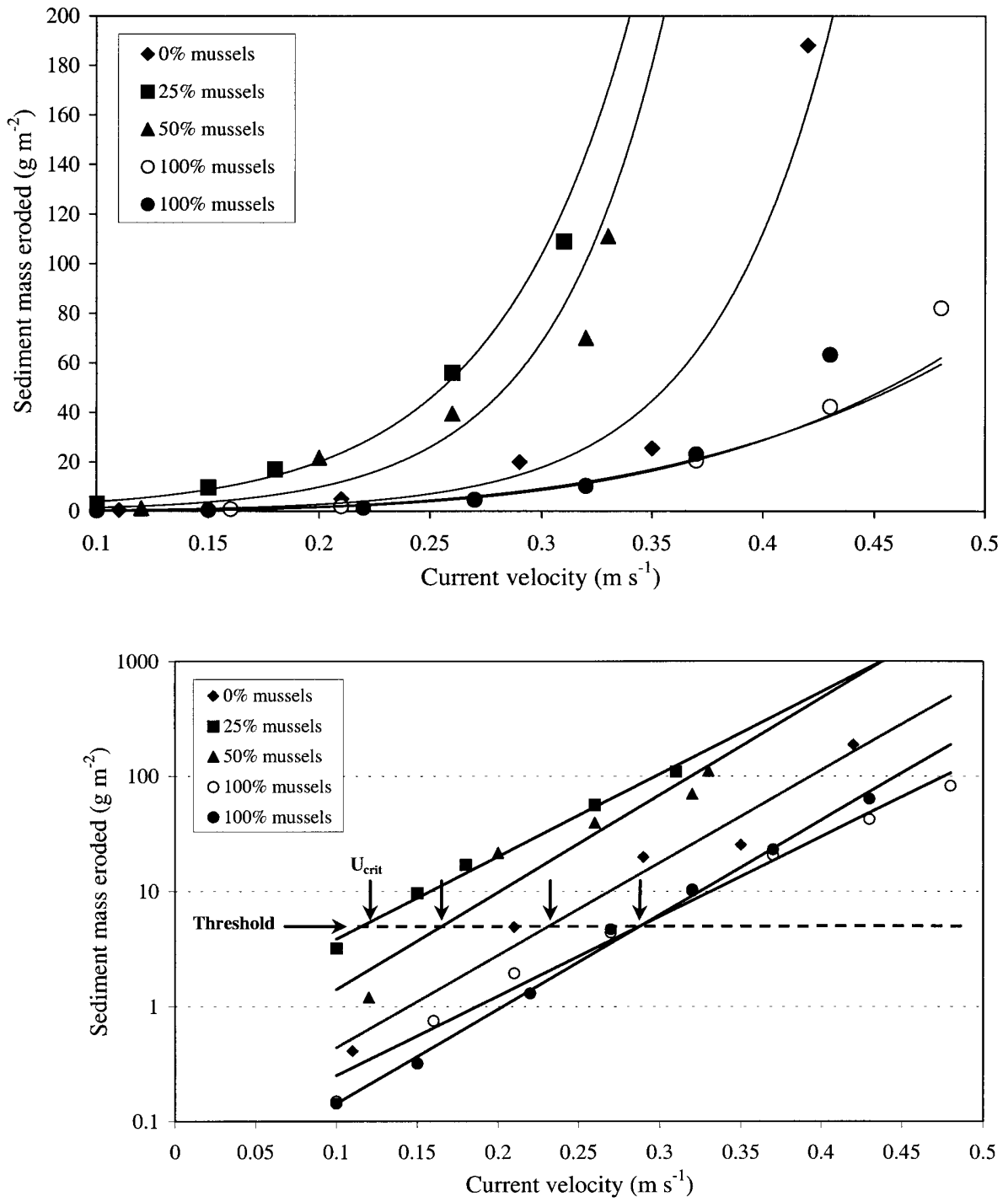

Table 2 Analysis of covariance comparing regression lines for log mass eroded versus current velocity for different mussel bed densities (\% cover) and substrates. There were no significant differences in the slopes of regression lines, but significant differences in intercepts ( $P$ values; n.s. - not significant)

\begin{tabular}{clllllll}
\hline $\begin{array}{l}\text { \% Mussel cover } \\
\text { and substrate }\end{array}$ & $\begin{array}{l}0 \% \\
\text { (sand) }\end{array}$ & $\begin{array}{l}25 \% \\
\text { (sand) }\end{array}$ & $\begin{array}{l}50 \% \\
\text { (sand) }\end{array}$ & $\begin{array}{l}100 \% \\
\text { (sand) }\end{array}$ & $\begin{array}{l}0 \% \\
\text { (pebble) }\end{array}$ & $\begin{array}{l}25 \% \\
\text { (pebble) }\end{array}$ & $\begin{array}{l}100 \% \\
\text { (pebble) }\end{array}$ \\
\hline $0 \%$ (sand) & - & & & & & & \\
$25 \%$ (sand) & $<0.001$ & - & & & & \\
$50 \%$ (sand) & $<0.001$ & n.s. & - & & & \\
$100 \%$ (sand) & $<0.01$ & $<0.001$ & $<0.001$ & - & & \\
$0 \%$ (pebble) & $<0.01$ & $<0.001$ & $<0.001$ & n.s. & - & \\
$25 \%$ (pebble) & $<0.001$ & $<0.001$ & $<0.001$ & n.s. & n.s. & - & \\
$100 \%$ (pebble) & $<0.05$ & $<0.001$ & $<0.001$ & n.s. & n.s. & n.s. & - \\
\hline
\end{tabular}

OBS sensor and erosion is expressed in terms of sediment mass eroded $\left(\mathrm{g} \mathrm{m}^{-2}\right)$ and mean erosion rate during the first $10 \mathrm{~min}$ of each step $\left(\mathrm{mg} \mathrm{m}^{-2} \mathrm{~s}^{-1}\right)$. Both show an exponential increase with current velocity. The relationships between sediment mass eroded and current velocity for different mussel bed densities on sandy sediment are presented in Fig. 4. In contrast to the bare sand $(0 \%$ cover), sediment resuspension was about five and four times higher for $25 \%$ and $50 \%$, respectively (Table 2; ANCOVA, $P<0.001)$. This was due to the increased tur- bulence and scouring around mussel clumps and resulted in some mussels detaching from the bed at the higher current velocities. Sediment erosion was lowest from the bed with 100\% mussel cover (Table 2; ANCOVA, $P<0.001)$ and the many byssal attachments between individuals prevented any detachment during erosion. The log-transformed regression lines (Fig. 5) were used to calculate critical erosion velocities $\left(U_{\text {crit }}\right)$, based on an erosion threshold value of $5 \mathrm{~g} \mathrm{~m}^{-2}$ (equivalent to a increase in SPM of $\left.20 \mathrm{mg} \mathrm{l}^{-1}\right)$. $U_{\text {crit }}$ values ranged from 
Fig. 6 Effect of current velocity on sediment mass eroded from pebble/sand substrate with different mussel bed densities (\% cover)

Fig. 7 Recovery of mussel bed following burial by sandy sediment during flume erosion experiments $(50 \%$ coverage on sandy substrate). After 1 day the mussels had moved upwards and the sediment had settled between and below the mussels

Fig. 8 Relationship between the mass ratio of sediment/ stones to attached mussels (degree of mussel anchorage) and the weight of mussel clumps or approximate percentage coverage (mussel bed density)
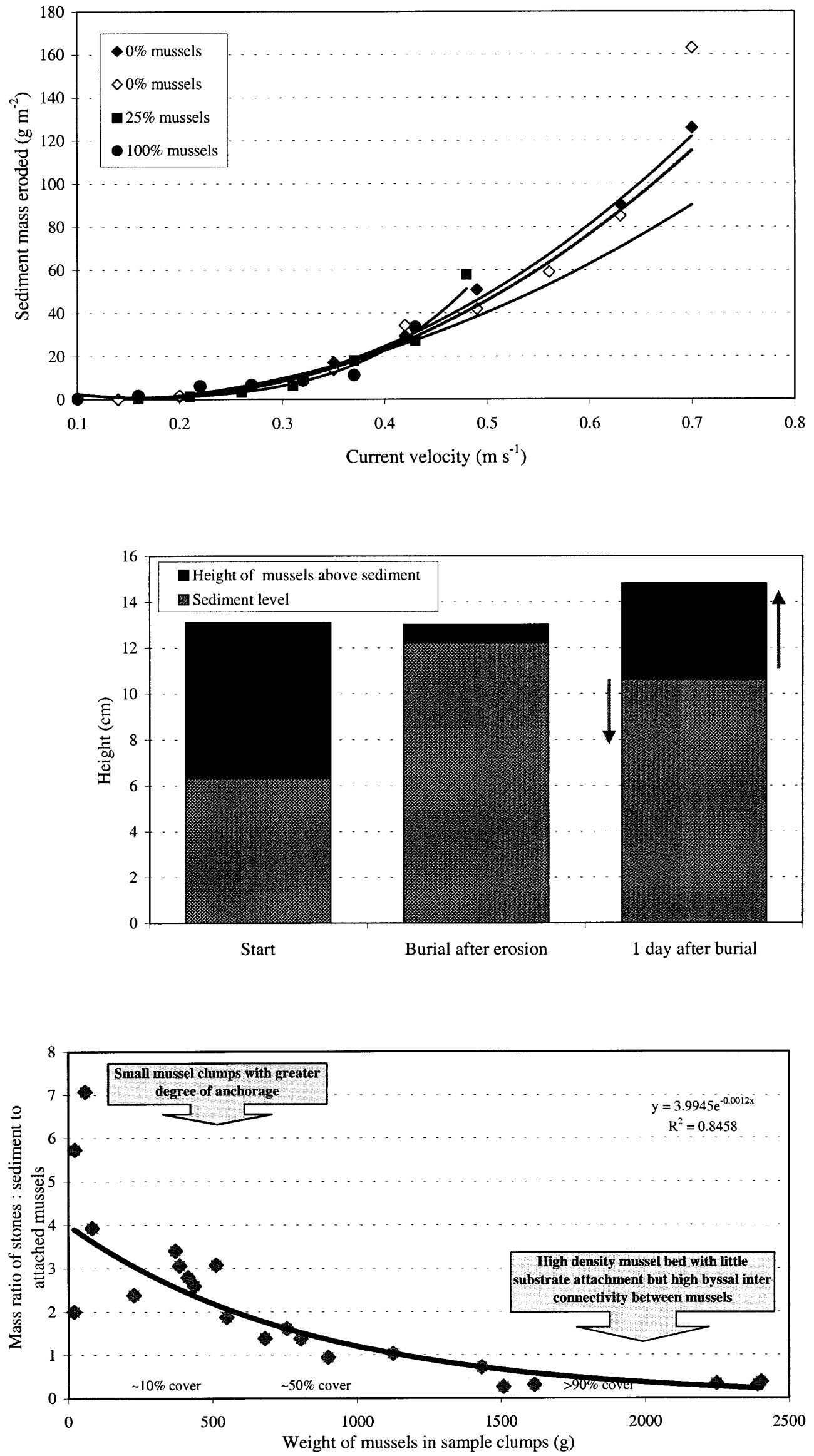
Fig. 9 Output from mini-rig placed on eastern edge of

Exmouth mussel bed (5 May 2000): water depth (m), concentration of suspended particulate matter $\left(S P M, \mathrm{mg} \mathrm{l}^{-1}\right)$, current velocity $\left(\mathrm{m} \mathrm{s}^{-1}\right)$ and flow direction $\left({ }^{\circ}\right.$ from magnetic north)
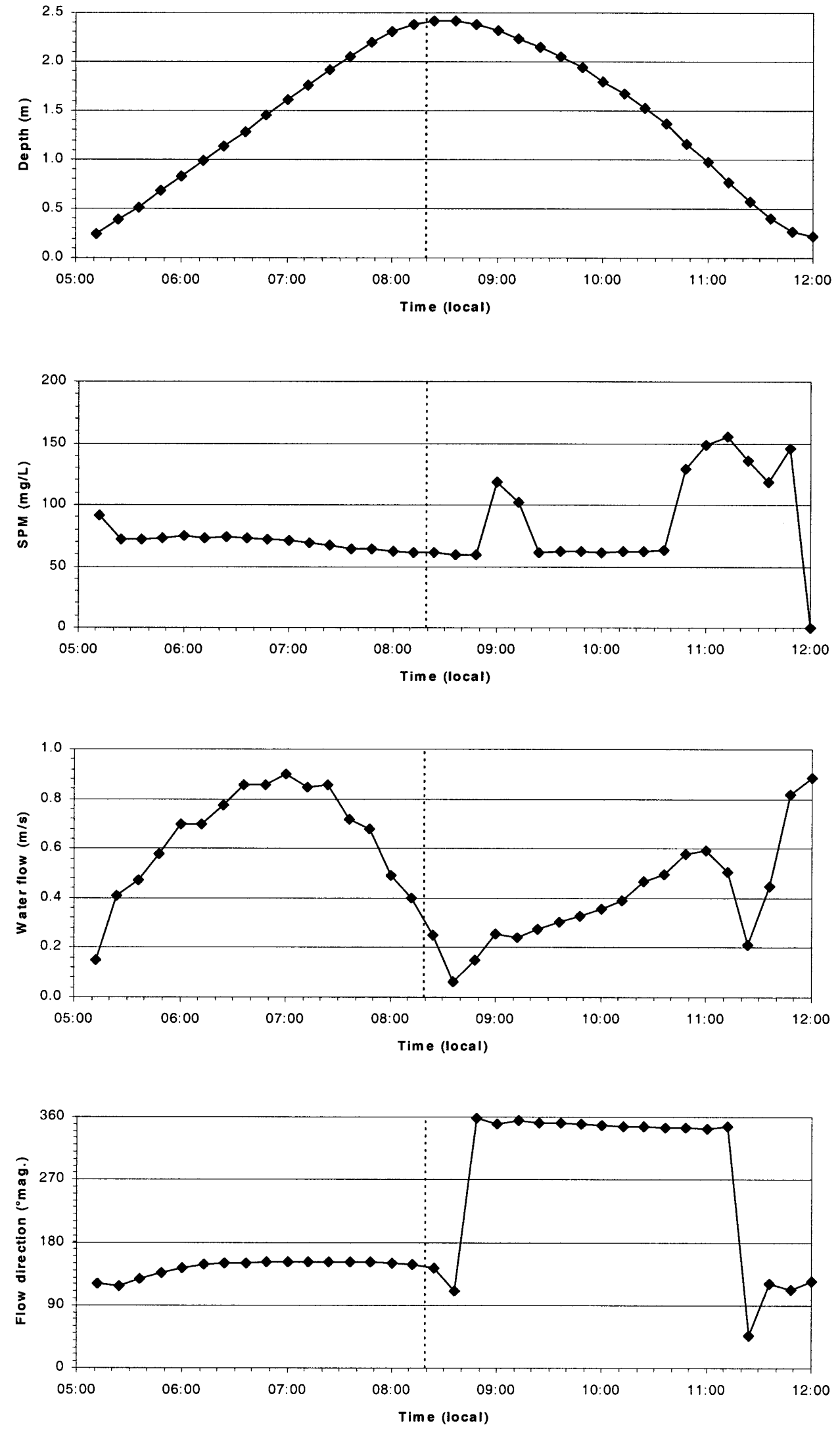
$0.12 \mathrm{~m} \mathrm{~s}^{-1}$ for $25 \%$ mussel cover, to $0.17 \mathrm{~m} \mathrm{~s}^{-1}$ for $50 \%$, $0.23 \mathrm{~m} \mathrm{~s}^{-1}$ for bare sand and $0.29 \mathrm{~m} \mathrm{~s}^{-1}$ for $100 \%$ mussel cover. Although $U_{\text {crit }}$ values for the pebble/sandy substrate were similar (i.e. $0.25 \mathrm{~m} \mathrm{~s}^{-1}$ ), erosion rates and the mass of sediment resuspended from the pebble/sandy substrate were low in contrast to the sandy substrate. Sediment erodability of the pebble/sandy substrate was low and independent of percentage mussel cover (Fig. 6; Table 2).

Following sediment erosion of the bed with 50\% mussel coverage, a large proportion of the mussels were buried with sand to a depth of $\sim 6 \mathrm{~cm}$ (Fig. 7) and a few individuals still had their posterior shell edges just above the sediment surface. Within 1 day the mussels had migrated upwards and the substrate had settled between and below the mussels (Fig. 7) and they had resumed suspension feeding.

At the higher current velocities in the flume, mussel clumps became detached from the substrate. As a result, a field survey of the Exmouth mussel bed examined the relationship between mussel clump mass and the size of the pebble/sediment anchorage attached. Figure 8 shows that the smaller mussel clumps have a greater degree of anchorage than the larger mussel clumps which rely more on the high degree of byssal interconnectivity between mussels within the clump.

Field measurement of current velocities over tidal cycle

During a spring tide of $4.5 \mathrm{~m}$ tidal amplitude there is $\sim 2.3 \mathrm{~m}$ of water over the mussel bed (>90\% cover) at high water. Current velocities near the eastern part of the mussel bed had a peak of $0.9 \mathrm{~m} \mathrm{~s}^{-1}$ at $\sim 1.5 \mathrm{~h}$ before and $\sim 3 \mathrm{~h}$ after high water, just prior to emersion of the bed (Fig. 9). The currents only declined to $<0.2 \mathrm{~m} \mathrm{~s}^{-1}$ for about $30 \mathrm{~min}$ at slack water. There was evidence of a complex 'bursting phenomenon' (Soulsby et al. 1994) at the beginning and end of the ebb tide as the flows were checked, causing enhanced turbulence and resuspension. Due to the strong tidal currents and the location of this site at approximately mid-tide level there was strong advection and no straightforward relationship between current velocity and SPM.

\section{Discussion}

Suspension feeding rate (clearance rate) by $M$. edulis was found to be independent of current velocities, at least between 0.05 and $0.8 \mathrm{~m} \mathrm{~s}^{-1}$. This is in contrast to previous studies by Wildish and Miyares (1990) and Newell (1999), who recorded behavioural changes and a marked decline in clearance rate by M. edulis from 0.05 to $0.25 \mathrm{~m} \mathrm{~s}^{-1}$, with very low clearance rates above $0.25 \mathrm{~m} \mathrm{~s}^{-1}$. The present findings, however, showing maintained clearance/feeding rates at current velocities $>0.25 \mathrm{~m} \mathrm{~s}^{-1}$ appear to be generally more consistent with field observations. For example, there is preferential

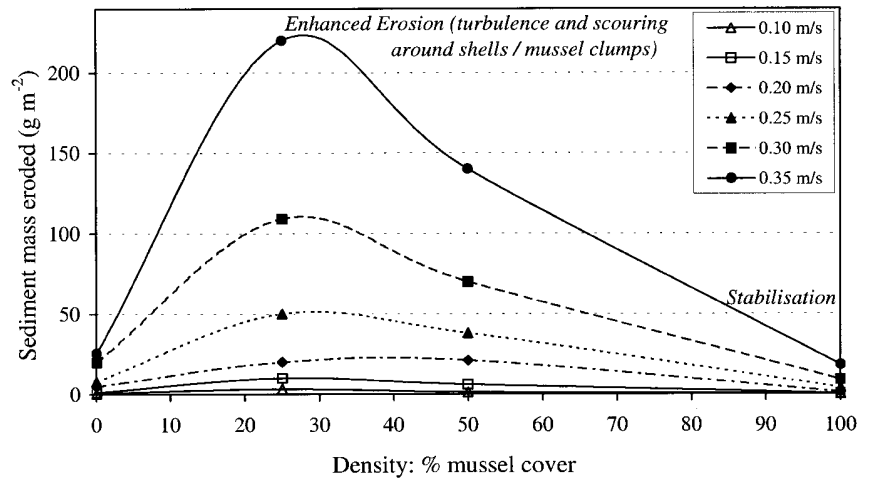

Fig. 10 Effect of mussel bed density (\% cover) and current velocity $\left(\mathrm{m} \mathrm{s}^{-1}\right)$ on sediment mass eroded from the bed (sandy substrate) at Exmouth (Exe estuary)

settlement and growth of mussels in areas of high currents, such as mouths of macrotidal estuaries and cooling water systems of electric power plants (Jenner et al. 1998). If currents $>0.25 \mathrm{~m} \mathrm{~s}^{-1}$ inhibited feeding, mussels living at Exmouth would only be able to feed for around $11 \%$ of the immersion time (Fig. 9). Jenner et al. (1998) found that biofouling of cooling water systems by mussels was only significantly reduced when the mean current velocities ranged from 1.8 to $2.2 \mathrm{~m} \mathrm{~s}^{-1}$, with a total absence at $>2.9 \mathrm{~m} \mathrm{~s}^{-1}$.

There appears to be no obvious explanation for the recorded differences between the present study and those of Wildish and Miyares (1990) and Newell (1999). Both these earlier studies were based on M. edulis from North America and the western side of the North Atlantic. This raises the question of whether these mussels are phenotypically or genotypically different from those on the eastern shores of the North Atlantic. While it is apparent that the tidal currents at study sites in Maine are relatively low (i.e. $0.05-0.30 \mathrm{~m} \mathrm{~s}^{-1}$ with a tidal amplitude of $3 \mathrm{~m}$; Newell and Shumway 1993) compared to Exmouth (Fig. 9), it is unlikely that the mussels studied by Wildish and Miyares (1990) were from areas of low tidal currents (i.e. St Andrews, New Brunswick; but tidal currents at the collection site were not reported). This apparent contradiction between declining feeding rate in response to velocity (Wildish and Miyares 1990) and field observations showing mussel production increasing as a function of velocity was highlighted by Wildish and Kristmanson (1993) but not resolved.

The effects of current velocity demonstrate a non-linear relationship between sediment erodability and mussel bed density on a sandy substrate (Fig. 10). The lower resuspension of sediment at $0 \%$ mussel cover, compared to $25 \%$ cover, is due in part to the lower turbulence resulting from the lower bed roughness, the movement of sand primarily as bedload transport, and the lower silt content due to the absence of biodeposits. The lowest $U_{\text {crit }}$ and the highest erosion rates were associated with the intermediate bed densities (25\% and 50\% mussel cover) and this was primarily due to scouring around the clumps of mussels. These findings were in contrast to the sediment 


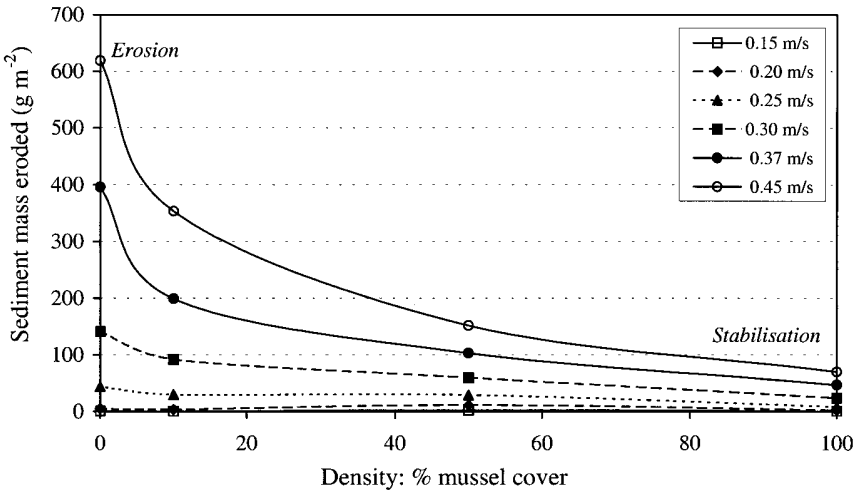

Fig. 11 Effect of mussel bed density (\% cover) and current velocity $\left(\mathrm{m} \mathrm{s}^{-1}\right)$ on sediment mass eroded from the bed (cohesive mud substrate) at Cleethorpes (Humber estuary)

erosion from a mussel bed over a more consolidated pebble/sand substrate, which showed a high degree of stability. The non-linear relationship on a sandy substrate also contrasts with previous flume studies (Widdows et al. 1998a) that demonstrated a more linear relationship between sediment erosion, current velocity and mussel density for a more cohesive muddy substrate (46\% silt) at Cleethorpes in the Humber estuary (Fig. 11).

Any reduction in mussel density will make the mussel bed more vulnerable to erosion induced by high current velocities (combined high ebb tidal flows and fluvial flows; e.g. Exmouth) and storms (wave action and maximum tidal flows; e.g. Cleethorpes). The results of the present study indicate that even a modest reduction (i.e. from $100 \%$ to $50 \%$ ) in the density/covering of mussel beds will enhance sediment erosion, resuspend biodeposits and make the bed more vulnerable. Consequently, the opening-up of mussel beds and the reduction in density as a result of commercial harvesting is likely to make mussel beds more vulnerable to erosion by tidal currents and storms, particularly in more open exposed areas (i.e. with a long fetch) and with a sandy substrate (e.g. Wash and Wadden Sea).

When mussels become buried by sandy sediment to a depth of at least $6 \mathrm{~cm}$, they are capable of rapid recovery and movement up to the surface within 1 day. The process of vertical movement by M. edulis was unclear, despite careful observations and analysis of video recordings. It may involve a combination of: (1) detachment of byssal threads from other mussels and the use of the foot to attach byssal threads to solid matter higher in the sediment column, (2) the use of the shell valves to lever the mussel up with the posterior edge upper-most, and (3) the use of ventilation currents to fluidise the bed in the immediate vicinity of the partially opened valves.

Channels on the edge of the main mussel beds at Exmouth experience high current velocities on spring tides $\left(0.9 \mathrm{~m} \mathrm{~s}^{-1}\right)$ and were characterised by a substrate of pebbles/sand and a range of bed densities. Mussels on the range of substrates found at Exmouth are able to sustain densities below $100 \%$ cover by increasing their attach- ment or degree of anchorage to the substrate with declining size of mussel clump (Fig. 8). The smaller mussel clumps $(<10 \%$ cover $)$ prevented detachment at high current velocities by maintaining a high degree of anchorage to the pebble/sandy substrate. Low density mussel clumps had approximately eight times greater anchorage than the high density patches of mussels that relied more on high byssal interconnectivity between mussels rather than to the substrate.

Acknowledgements This study was supported by an Internal Research Allowance from James Cook University to J.S.L. The study was conducted at Plymouth Marine Laboratory while J.S.L. was on Special Study Leave from James Cook University. We thank Colin Barrett for developing the mini-rig and the controller/datalogger for the flume.

\section{References}

Asmus H, Asmus RM (1993) Phytoplankton-mussel bed interactions in intertidal ecosystems. In: Dame RF (ed) Bivalve filter feeders in estuarine and coastal processes. (NATO ASI series, vol G33) Springer, Berlin Heidelberg New York, pp 57-84

Asmus H, Asmus RM, Prins TC, Dankers N, Frances G, Maass B, Reise K (1992) Benthic-pelagic flux rates on mussel beds: tunnels and tidal flume methodology compared. Helgol Meeresunters 46:341-361

Collins MB, Amos CL, Evans G (1981) Observations of some sediment transport processes over intertidal flats in the Wash, UK. (Special publication, vol 5) International Association of Sedimentologists, Oxford, pp 81-98

Dame RF (1993) The role of bivalve filter feeder material fluxes in estuarine ecosystems. In: Dame RF (ed) Bivalve filter feeders in estuarine and coastal processes. (NATO ASI series, vol G33) Springer, Berlin Heidelberg New York, pp 245-270

Fréchette M, Bourget E (1985) Food-limited growth of Mytilus edulis in relation to the benthic boundary layer. Can J Fish Aquat Sci 42:1166-1170

Fréchette M, Lefaivre D, Butman CA (1993) Bivalve feeding and the benthic boundary layer. In: Dame RF (ed) Bivalve filter feeders in estuarine and coastal processes. (NATO ASI series, vol G33) Springer, Berlin Heidelberg New York, pp 325-369

Fukada MK, Lick W (1980) The entrainment of cohesive sediment in freshwater. J Geophys Res 85:2813-2824

Jenner HA, Whitehouse JW, Taylor CJL, Khalanski M (1998) Cooling water management in European power stations: biology and control of fouling. Hydroecol Appl 1-2:1-225

McGrorty S, Clarke RT, Reading CJ, Goss-Custard JD (1990) Population dynamics of the mussel Mytilus edulis: density changes and regulation of the population in the Exe estuary, Devon. Mar Ecol Prog Ser 67:157-169

Newell CR (1999) The effects of current speed and particle concentration on mussel (Mytilus edulis) filtration rate: a recirculating flume study (conference abstract). J Shellfish Res 18

Newell CR, Shumway SE (1993) Grazing of natural particulates by bivalve molluscs: a spatial and temporal perspective. In: Dame RF (ed) Bivalve filter feeders in estuarine and coastal processes. (NATO ASI series, vol G33) Springer, Berlin Heidelberg New York, pp 85-148

Paterson DM, Black KS (1999) Water flow, sediment dynamics and benthic biology. Adv Ecol Res 29:155-193

Prins TC, Smaal AC, Pouer AJ, Dankers N (1996) Filtration and resuspension of particulate matter and phytoplankton on an intertidal mussel bed in the Oosterschelde estuary (SW Netherlands). Mar Ecol Prog Ser 142:121-134

Soulsby RL, Atkins R, Salkield AP (1994) Observations of the turbulent structure of a suspension of sand in a tidal current. Cont Shelf Res 14:429-435 
Widdows J, Brinsley MD, Salkeld PN, Elliott M (1998a) Use of annular flumes to determine the influence of current velocity and biota on material flux at the sediment-water interface. Estuaries 21:552-559

Widdows J, Brinsley MD, Bowley N, Barrett C (1998b) A benthic annular flume for in situ measurement of suspension feeding/biodeposition rates and erosion potential of intertidal cohesive sediments. Estuar Coast Shelf Sci 46:27-38

Widdows J, Brinsley MD, Salkeld PN, Lucas CH (2000) Influence of biota on spatial and temporal variation in sediment erod- ability and material flux on a tidal flat (Westerschelde, The Netherlands). Mar Ecol Prog Ser 194:23-37

Wildish DJ, Kristmanson DD (1993) Hydrodynamic control of bivalve filter feeders: a conceptual view. In: Dame RF (ed) Bivalve filter feeders in estuarine and coastal processes. (NATO ASI series, vol G33) Springer, Berlin Heidelberg New York, pp 299-324

Wildish DJ, Miyares MP (1990) Filtration rate of blue mussels as a function of flow velocity: preliminary experiments. J Exp Mar Biol Ecol 142:213-219 